\title{
Residual Gas for Ethanol Production by Clostridium carboxidivorans in a Dual Impeller Stirred Tank Bioreactor (STBR)
}

\author{
Carolina Benevenuti $^{1,2}{ }^{(D}$, Marcelle Branco $^{3}$, Mariana do Nascimento-Correa ${ }^{1,2}$, Alanna Botelho ${ }^{1}$, \\ Tatiana Ferreira $^{3}$ (D) and Priscilla Amaral ${ }^{1, *(\mathbb{D})}$
}

1 Department of Biochemical Engineering, School of Chemistry, Universidade Federal do Rio de Janeiro, Rio de Janeiro 21941-909, RJ, Brazil; carolbenevenuti@hotmail.com (C.B.); marianamattosquim@gmail.com (M.d.N.-C.); lanna.mbotelho@gmail.com (A.B.)

2 Technology Center for Chemical and Textile Industry, SENAI Innovation Institute for Biosynthetics, Rio de Janeiro 21941-909, RJ, Brazil

3 Department of Organic Process, School of Chemistry, Universidade Federal do Rio de Janeiro, Rio de Janeiro 21941-909, RJ, Brazil; cellebranco@gmail.com (M.B.); tatiana@eq.ufrj.br (T.F.)

* Correspondence: pamaral@eq.ufrj.br; Tel.: +55-21-3938-7623

check for updates

Citation: Benevenuti, C.; Branco, M.; do Nascimento-Correa, M.; Botelho, A.; Ferreira, T.; Amaral, P. Residual Gas for Ethanol Production by Clostridium carboxidivorans in a Dual Impeller Stirred Tank Bioreactor (STBR). Fermentation 2021, 7, 199. https://doi.org/10.3390/

fermentation7030199

Academic Editor: Alessia Tropea

Received: 26 August 2021

Accepted: 17 September 2021

Published: 21 September 2021

Publisher's Note: MDPI stays neutral with regard to jurisdictional claims in published maps and institutional affiliations.

\begin{abstract}
Recycling residual industrial gases and residual biomass as substrates to biofuel production by fermentation is an important alternative to reduce organic wastes and greenhouse gases emission. Clostridium carboxidivorans can metabolize gaseous substrates as $\mathrm{CO}$ and $\mathrm{CO}_{2}$ to produce ethanol and higher alcohols through the Wood-Ljungdahl pathway. However, the syngas fermentation is limited by low mass transfer rates. In this work, a syngas fermentation was carried out in serum glass bottles adding different concentrations of Tween $\AA 80$ in ATCC 2713 culture medium to improve gas-liquid mass transfer. We observed a $200 \%$ increase in ethanol production by adding $0.15 \%(v / v)$ of the surfactant in the culture medium and a $15 \%$ increase in biomass production by adding $0.3 \%$ $(v / v)$ of the surfactant in the culture medium. The process was reproduced in stirred tank bioreactor with continuous syngas low flow, and a maximum ethanol productivity of $0.050 \mathrm{~g} / \mathrm{L} . \mathrm{h}$ was achieved.
\end{abstract}

Keywords: synthesis gas fermentation; volumetric mass transfer coefficient; Tween $80 ®$ surfactant

\section{Introduction}

Global energy consumption has increased over the last decades, with demand forecasted to be 248 quadrillions BTU of liquid fuels by 2050, which represents an increase of $50 \%$ compared to 2021 [1]. The use of fossil-based energy has been declining since its use drives climate changes and air pollution [2]. Additionally, the constant fluctuation of oil prices caused by political and economic instability around the world brings insecurity to this industrial sector [3].

In this scenario, there is an increasing demand for renewable and carbon-neutral fuels, especially those produced through microbial fermentation, such as ethanol and butanol $[4,5]$. Initially, ethanol was the main focus, which can either be a stand-alone fuel or a gasoline-ethanol blend [4]. However, its low caloric value and hygroscopicity limit the use and transportation of ethanol in the current infrastructure. Therefore, the interest in butanol as a liquid fuel, which is less hygroscopic and provides higher caloric value in comparison to ethanol, has increased in recent years [6]. Currently, those alcohols are produced through direct fermentation of sugars extracted from food or energy crops, with pretreatment steps to hydrolyze carbohydrate polymers, increasing costs and byproduct formation $[7,8]$.

The indirect fermentation, or hybrid process, consists of the conversion of a wide variety of carbonaceous compounds to synthesis gas, also named syngas, through gasification, followed by its fermentation to desired products by specific biocatalysts $[9,10]$. Syngas, 
mainly composed of $\mathrm{CO}$ (carbon monoxide), $\mathrm{CO}_{2}$ (carbon dioxide), and $\mathrm{H}_{2}$ (hydrogen), can be obtained from biomass, coal, animal or municipal solid waste, and industrial CO-rich off-gases [11]. The hybrid process uses whole biomass components, including lignin, is not dependent on feedstock composition, and eliminates complex pretreatments and high enzyme costs [12].

Several Clostridium species are known to produce biofuels, but only a few of them use syngas as sole carbon and energy sources [13]. Clostridium carboxidivorans is an acetogenic bacteria capable of producing ethanol, butanol, and hexanol-valuable as fuels or even as platform chemicals in the pharmaceutical, perfume, and textile industries-from syngas [5,14-17].

Although syngas fermentation is a promising technology, it faces several challenges: low product yield, high separation cost, inhibitory compounds in syngas (i.e., tar, sulfur, and ash), and, mainly, low gas-liquid mass transfer [11,12,18-20]. Metabolic engineering, culture medium formulation, and different bioreactor designs have been proposed to overcome those challenges $[11,21]$.

Efforts to increase the gas-liquid mass transfer usually include the study of different reactor designs such as stirred tank reactor (STR) [14,22], bubble column reactor (BCR) [23], hollow fiber membrane reactor (HFMR) [24], monolithic biofilm reactor (MBR) [23], trickle bed reactor (TBR) [25], and horizontal rotating packed bed biofilm reactor (h-RPB) [26]. STR is the most usual bioreactor used for biotechnology due to its good mixing and simple operation. A widely used approach to enhance mass transfer in STR is to increase the agitation speed and the gas flow rate. However, these strategies are not economically feasible to scale up due to the high energy consumption and microbial shear stress [11].

Another feasible approach to enhance gas-liquid mass transfer is to add some chemical agents, such as surfactants, or some vibration techniques in the culture medium to promote fine gas bubbles in the liquid phase [27-29]. The addition of surfactants in the culture medium enables the stabilization of microbubbles, avoiding coalescence. These agents can reduce interfacial free energy, reducing the liquid surface tension [30]. Coelho et al. [20] reported a significant increase $(120 \%)$ in carbon monoxide mass transfer coefficient when Tween ${ }^{\circledR} 80$ and/or PFC (perfluorocarbon) were added to water. Carbon monoxide fermentation by Butyribacterium methylotrophicum using Tween and Brij surfactants showed that only the Tween surfactants did not affect bacterial growth, and Tween ${ }^{\circledR} 80$ showed a higher growth rate, comparatively [29]. Tween surfactants seem to be non-toxic and do not inhibit cell growth $[29,31,32]$. This approach can maintain the simplicity of STR with the advantage of high mass transfer coefficients, typical of HFMR that are difficult to operate and scale up [33].

In this study, we evaluated the effect of different concentrations of Tween ${ }^{\circledR} 80$ in ATCC ${ }^{\circledR} 2713$ culture medium for Clostridium carboxidovorans syngas fermentation in $100 \mathrm{~mL}$ serum bottles, and the best condition was validated in a stirred tank bioreactor (STBR).

\section{Materials and Methods}

\subsection{Materials}

Peptone, sodium pyruvate, tryptone, yeast extract, sodium dithionite, glucose, hemin, L-arginine, and menadione were obtained from Sigma-Aldrich (São Paulo, Brazil). Sodium chloride was obtained from Vetec (Rio de Janeiro, Brazil) and Tween ${ }^{\circledR} 80$ from Isofar (Rio de Janeiro, Brazil). Syngas was provided by White Martins Praxair Inc. (Rio de Janeiro, Brazil) in a pressurized cylinder with a pre-established composition, based on gas obtained from pyrolysis of urban wastes (MAIM/INNOVA technology, [34]): 25\% CO, 43.9\% $\mathrm{H}_{2}$, $10.02 \% \mathrm{CO}_{2}, 10.05 \% \mathrm{~N}_{2}$, and $11.01 \% \mathrm{CH}_{4}$.

\subsection{Strain, Culture Medium, and Inoculum Preparation}

Clostridium carboxidivorans DSM15243 was obtained from Deutsche Sammlung von Mikroorganismen und Zellkulturen GmbH (DSMZ, Braunschweig, Germany). The cells were activated, stored, and grown under anaerobic condition in $50 \mathrm{~mL}$ serum bottles 
containing $30 \mathrm{~mL}$ of TPYarg (Tryptone, Peptone, Yeast extract, and arginine) medium, containing the following composition (per liter): tryptone, $12 \mathrm{~g}$; peptone, $12 \mathrm{~g}$; yeast extract, $7 \mathrm{~g}$; L-arginine, $1.2 \mathrm{~g}$ [5]. Syngas was flushed in the liquid phase for $5 \mathrm{~min}$, and then all serum glass bottles were sealed with gas impermeable butyl rubber septum stoppers and aluminum seals. These bottles were autoclaved at $121^{\circ} \mathrm{C}$ for $20 \mathrm{~min}$ for sterilization, inoculated ( $0.05 \mathrm{~g}$ dry weight cell/L) after cooling, followed by syngas addition in the headspace for $1 \mathrm{~min}$. For both activation and growth, bottles were incubated for 48 and $24 \mathrm{~h}$, respectively, in a horizontal position [35] at $37^{\circ} \mathrm{C}$ and $150 \mathrm{rpm}$ in Infors HT-Multitron Pro shaker.

\subsection{Syngas Fermentation in Serum Glass Bottles}

All fermentations were performed in $100 \mathrm{~mL}$ serum glass bottles containing $50 \mathrm{~mL}$ of ATCC ${ }^{\circledR} 2713$ (tryptone, $10 \mathrm{~g} / \mathrm{L}$; gelatin peptone, $10 \mathrm{~g} / \mathrm{L}$; yeast extract, $5 \mathrm{~g} / \mathrm{L}$; glucose, $1 \mathrm{~g} / \mathrm{L}$; sodium chloride, $5 \mathrm{~g} / \mathrm{L}$; L-arginine, $1 \mathrm{~g} / \mathrm{L}$; sodium pyruvate, $1 \mathrm{~g} / \mathrm{L}$; menadione, $0.5 \mathrm{mg} / \mathrm{L}$ and hemin, $5 \mathrm{mg} / \mathrm{L})$ culture medium with different concentrations of Tween ${ }^{\circledR} 80(0,0.07 \%$, $0.15 \%$ and $0.3 \% \mathrm{v} / \mathrm{v}$ ). After mediums preparation, nitrogen was flushed in the liquid phase for $30 \mathrm{~min}$, and then syngas was flushed in the liquid phase for $5 \mathrm{~min}$. The glass bottles were sealed with gas impermeable butyl rubber septum stoppers and aluminum seals and sterilized in an autoclave at $0.5 \mathrm{~atm}$ for $20 \mathrm{~min}$. After sterilization, seed culture was aseptically inoculated in all glass bottles to achieve $0.05 \mathrm{~g}$ dry weight of cells/L. Syngas was aseptically added in the headspace, and the bottles were incubated horizontally at $37^{\circ} \mathrm{C}$ and $150 \mathrm{rpm}$ in Infors HT Multitron shaker. Cell growth was measured in real-time through non-invasive technology using Cell Growth Quantifier (CGQ) sensors from Aquila Biolabs, collecting biomass concentration data every $30 \mathrm{~s}$. Biomass concentration was measured through an equipment particular optical unit (backscatter), which is converted to optical density at $600 \mathrm{~nm}\left(\mathrm{OD}_{600}\right)$ by a standard curve previously obtained in CGQ. Fermented culture mediums were sampled for high-performance liquid chromatography (HPLC) analysis.

\subsection{Syngas Fermentation in Stirred Tank Bioreactor}

Syngas fermentation was conducted in a 1-L cylindrical stirred tank reactor (TECBIO-1.5, Tecnal Scientific Equipment Co., Piracibada, SP, Brazil) with an internal diameter of $9 \mathrm{~cm}$ and a maximum working volume of $1.0 \mathrm{~L}$. The production medium $(0.75 \mathrm{~L})$ was the ATCC ${ }^{\circledR} 2713$ medium (tryptone, $10 \mathrm{~g} / \mathrm{L}$; gelatin peptone, $10 \mathrm{~g} / \mathrm{L}$; yeast extract, $5 \mathrm{~g} / \mathrm{L}$; glucose, $1 \mathrm{~g} / \mathrm{L}$; sodium chloride, $5 \mathrm{~g} / \mathrm{L} ; \mathrm{L}$-arginine, $1 \mathrm{~g} / \mathrm{L}$; sodium pyruvate, $1 \mathrm{~g} / \mathrm{L}$; menadione, $0.5 \mathrm{mg} / \mathrm{L}$ and hemin, $5 \mathrm{mg} / \mathrm{L}$ ) with Tween ${ }^{\circledR} 80$, when its effect was validated. The bioreactor containing the production medium was autoclaved at $121^{\circ} \mathrm{C}$ for $20 \mathrm{~min}$, and, after cooling (room temperature), an inert gas $\left(\mathrm{N}_{2}\right)$ was flushed in liquid phase for $60 \mathrm{~min}$. Then, syngas was flushed in the liquid for $30 \mathrm{~min}$, and seed culture was inoculated just after under aseptic conditions to an initial cell concentration of $0.05 \mathrm{~g}$ dry weight of cells/L. The temperature was set at $37^{\circ} \mathrm{C}$, and medium was recirculated through a peristaltic pump coupled to the bioreactor at each sampling. Samples were withdrawn from the recycle line using an infusion set (Wiltex, $0.64 \mathrm{~mm} \times 19 \mathrm{~mm}$ ) and a $3.0 \mathrm{~mL}$ syringe (BD Plastipak).

Agitation speed was set at $300 \mathrm{rpm}$ with a six-bladed Smith impeller (radial flow impeller $4.0 \mathrm{~cm}$ above the vessel bottom) and a six-bladed Rushton impeller (radial flow impeller $11.5 \mathrm{~cm}$ above the vessel bottom). Syngas was continuously supplied at the bottom of the bioreactor with a gas flow rate of $0.5 \mathrm{~L} / \mathrm{min}$ controlled by a rotameter (Matheson, model FM-1000 VIH). The schematic diagram of the stirred tank reactor (STR) is shown in Figure 1. 


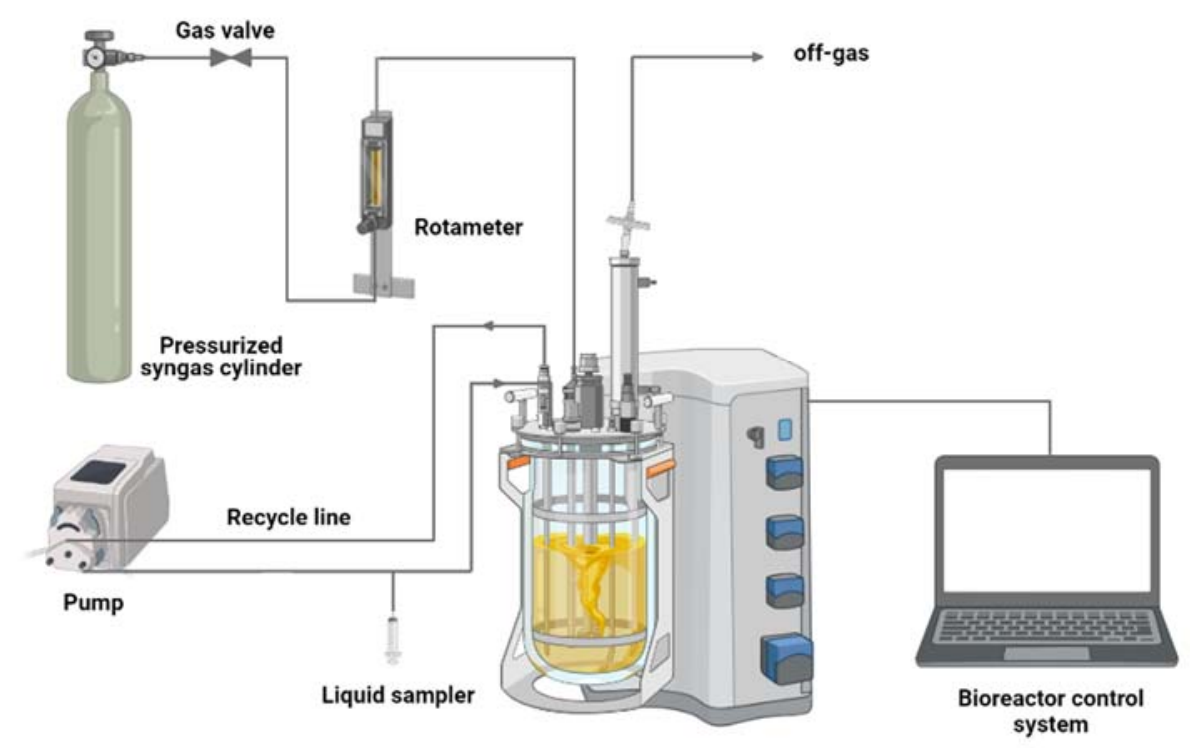

Figure 1. Schematic diagram of STBR used for C. carboxidivorans syngas fermentation. Created in Biorender.com (accessed on 13 July 2021).

Cell dry weight concentration (g dry weight of cells/L) was estimated by optical density measurement at $600 \mathrm{~nm}\left(\mathrm{OD}_{600}\right)$. The $\mathrm{OD}_{600}$ was measured using a UV-VIS spectrophotometer (Shimadzu UV-1800). Cell dry weight concentration was determined using a standard curve previously obtained.

\subsection{Analytical Methods}

\subsubsection{Dry Weight Cell}

The direct dry weight cell was obtained through filtration and drying protocol. Fivemilliliter samples of fermented culture medium were filtered using a $0.22 \mu \mathrm{m}$ membrane and dried to constant weight at $60^{\circ} \mathrm{C}$ using an incubator from Memmert IF55. The dry weight cell per liter was calculated using the cell weight and the sample volume.

\subsubsection{Metabolites Analyses}

Acetic acid, ethanol, and butanol were analyzed by HPLC (High-Performance Liquid Chromatography) from Shimadzu equipped with Aminex ${ }^{\circledR}$ HPX-87 H, $300 \times 7.8$ mm (BioRad Laboratories Ltd., Mississauga, ON, Canada) column and RI (refractive index) detector $\left(\right.$ Shimadzu ${ }^{\circledR}$ ). The mobile phase was $\mathrm{H}_{2} \mathrm{SO}_{4} 5 \mathrm{mM}$ at $0.6 \mathrm{~mL} / \mathrm{min}$ flow rate. The column temperature was set at $55^{\circ} \mathrm{C} .20 \mu \mathrm{L}$ of centrifuged and filtered samples were automatically injected into the equipment. The quantification of each metabolite was performed through an external standard (ESTD) curve previously obtained at specific retention times (acetic acid, $14.911 \mathrm{~min}$; ethanol, $22.080 \mathrm{~min}$ and butanol, $37.074 \mathrm{~min}$ ).

\section{Results and Discussion}

\subsection{Serum Bottles Fermentation}

\subsubsection{Cell Growth}

Syngas fermentation by $C$. carboxidivorans in serum bottles with ATCC ${ }^{2} 213$ medium and different Tween ${ }^{8} 80$ concentrations $(0,0.07 \%, 0.15 \%$, and $0.3 \%(v / v))$ was monitored during $120 \mathrm{~h}$. Cell dry weight per liter obtained by the CGQ equipment is depicted in Figure 2. A short lag phase was observed for all medium tested, probably due to the presence of glucose in the culture medium. This carbohydrate is quickly metabolized by C. carboxidivorans as a preferential substrate for heterotrophic growth. 


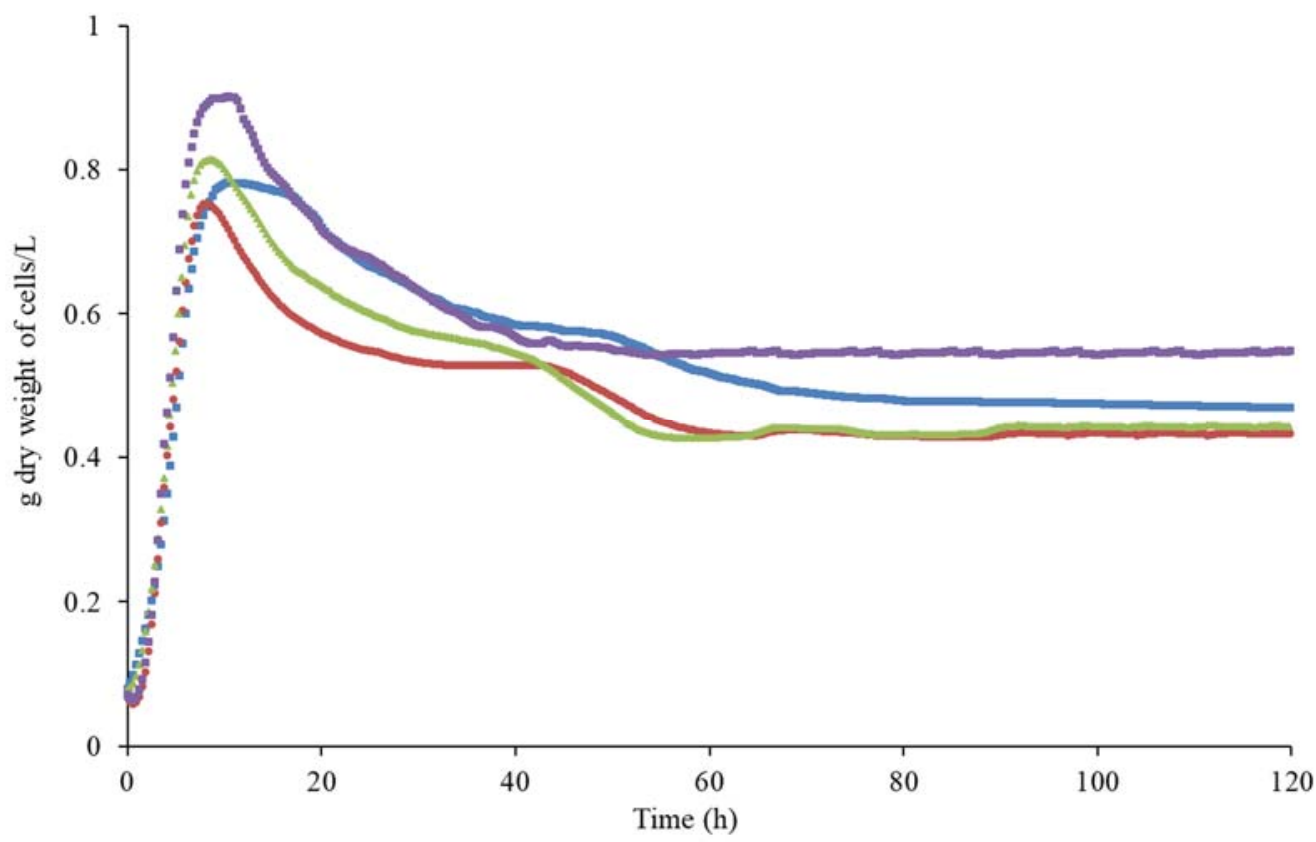

Figure 2. Cell growth of Clostridium carboxidivorans during syngas fermentation in the following media: ATCC $₫ 2713$ (blue square), ATCC $₫ 2713$ with $0.07 \%(v / v)$ Tween $\AA 80$ (red circle), ATCC $₫ 2713$ with $0.15 \%(v / v)$ Tween $\AA 80$ (green triangle), and ATCC $\AA 2713$ with $0.3 \%(v / v)$ Tween $₫ 80$ (purple square).

C. carboxidivorans growth profiles in ATCC $₫ 2713$ medium with different concentrations of Tween $® 80$ were similar. The maximum biomass concentration for all media was detected after about $10 \mathrm{~h}$ due to fast glucose consumption, followed by an accented drop until approximately $50 \mathrm{~h}$. After that, it stabilized at approximately $0.5-0.6 \mathrm{~g} / \mathrm{L}$. This growth profile has been shown for syngas batch fermentations with $C$. carboxidivorans in other works $[22,36,37]$. Since syngas is not continuously fed in serum bottles, cell growth reaches the stationary phase, when there is a balance between growth and death of cells. Fernández-Naveira et al. [36] showed that ethanol causes inhibition of cell growth. So, without substrate supply and with a toxic compound being produced, it is possible that cell death overlaps cell growth, and autolysis may occur, reducing turbidity [38].

Higher biomass concentration was obtained in medium with $0.3 \%$ Tween ${ }^{\circledR} 80(0.9 \mathrm{~g}$ dry weight of cells / L after $10 \mathrm{~h}$ ), $15 \%$ more compared to pure ATCC ${ }^{\circledR} 2713$ medium. After $120 \mathrm{~h}$ of fermentation, the medium with $0.3 \%$ Tween ${ }^{\circledR} 80$ also showed the highest final biomass concentration ( $0.52 \mathrm{~g}$ dry weight of cells $/ \mathrm{L})$ among all other conditions. This might be related to the beneficial effect of Tween ${ }^{\circledR} 80$ in $\mathrm{CO}$ and $\mathrm{CO}_{2}$ assessment after glucose exhaustion.

The specific growth rates of the fermentations with different Tween ${ }^{\circledR} 80$ concentrations were also very similar (Table 1), with a higher value for the medium with $0.3 \%$ Tween ${ }^{\circledR} 80$.

Table 1. Specific Clostridium carboxidivorans growth rate in ATCC $₫ 2713$ medium with different concentrations of Tween ${ }^{\circledR} 80$.

\begin{tabular}{|c|c|}
\hline Culture Medium & $\mu\left(h^{-1}\right)$ \\
\hline $\mathrm{ATCC}^{\circledR} 2713$ & $0.310 \pm 0.13$ \\
\hline ATCC $^{\circledR} 2713+0.07 \%$ Tween ${ }^{\circledR} 80$ & $0.359 \pm 0.12$ \\
\hline ATCC $^{\circledR} 2713+0.15 \%$ Tween ${ }^{\circledR} 80$ & $0.350 \pm 0.06$ \\
\hline ATCC $^{\circledR} 2713+0.3 \%$ Tween $^{\circledR} 80$ & $0.414 \pm 0.04$ \\
\hline
\end{tabular}

Considering that Tween $₫ 80$ can physically interact with dispersed bubbles in the liquid, causing emulsion formation, we did not know if CGQ sensors would generate wrong $\mathrm{OD}_{600}$ measurements due to the different concentrations of surfactant in the medium, 
leading to false biomass concentration data. To confirm the final OD measured by CGQ sensors, cell dry weight direct determination was performed after $120 \mathrm{~h}$ of fermentation. The results obtained showed that the $\mathrm{OD}_{600}$ measured by CGQ sensors were reliable since the conditions that led to lower or higher cell concentration were the same with both measurements, as shown in Table 2.

Table 2. Clostridium carboxidivorans cell concentration (g dry weight of cells/L) after $120 \mathrm{~h}$ of syngas fermentation obtained by CGQ measurement and calculated by direct cell dry weight measurement for different media.

\begin{tabular}{|c|c|c|}
\hline Culture Medium & CGQ Measurement & Direct Cell Dry Weight \\
\hline $\mathrm{ATCC}^{\circledR} 2713$ & $0.477 \pm 0.023$ & $0.433 \pm 0.156$ \\
\hline ATCC $^{\circledR} 2713+0.07 \%$ Tween ${ }^{\circledR} 80$ & $0.390 \pm 0.003$ & $0.413 \pm 0.065$ \\
\hline ATCC $^{\circledR} 2713+0.15 \%$ Tween ${ }^{\circledR} 80$ & $0.475 \pm 0.054$ & $0.443 \pm 0.075$ \\
\hline ATCC $^{\circledR} 2713+0.3 \%$ Tween ${ }^{\circledR} 80$ & $0.520 \pm 0.019$ & $0.477 \pm 0.015$ \\
\hline
\end{tabular}

\subsubsection{Metabolites Production}

Gaseous substrates are assimilated by acetogenic bacteria through the Wood-Ljungdahl pathway producing acetyl-CoA, an important intermediate to acids and alcohols production. Most acetogenics show a defined pattern of metabolites production, in which acids are produced in a first stage called acetogenesis, followed by the conversion of these acids into the respective alcohols, called solventogenesis. Ethanol production by Clostridium carboxidivorans has its particularities. It can be produced either directly from acetyl-CoA in a two-step reaction via acetaldehyde, requiring 4 molecules of $\mathrm{NADH}$, or via acetate and subsequent reduction to acetaldehyde, producing 1 molecule of ATP and consuming $4 \mathrm{NADH}$ per molecule of ethanol produced. Therefore, acetic acid produced during syngas fermentation by Clostridium carboxidivorans is an important indicator of potential ethanol production [39].

In our previous studies, we have identified that ethanol production by this strain in ATCC $^{\circledR} 2713$ medium increases gradually until $24 \mathrm{~h}$, then stabilizes. In other culture mediums, it starts to increase again after $70 \mathrm{~h} \mathrm{[5]} \mathrm{So,} \mathrm{we} \mathrm{decided} \mathrm{to} \mathrm{sample} \mathrm{serum} \mathrm{bottle} \mathrm{fer-}$ mentations at strategic points $(24 \mathrm{~h}$ - the first peak, $96 \mathrm{~h}$-the second peak, and then $120 \mathrm{~h}$, to verify final stabilization) to avoid volume reduction. Higher acetic acid concentration was obtained in pure ATCC $® 2713$ medium $(4.44 \mathrm{~g} / \mathrm{L})$ after $120 \mathrm{~h}$ of syngas fermentation, which is $85 \%$ more than the amount obtained in ATCC $® 2713$ medium containing Tween ${ }^{\circledR} 80$ (2.3 g/L) (Figure 3).

Despite this higher acetic acid concentration in the medium without the surfactant, higher ethanol production was detected after $96 \mathrm{~h}$ of syngas fermentation in ATCC®2713 medium with $0.15 \%(v / v)$ Tween $₫ 80(1.90 \mathrm{~g} / \mathrm{L})$ (Figure 4$)$. This value is 3.2 fold higher than that obtained using pure ATCC $® 2713$ medium $(0.58 \mathrm{~g} / \mathrm{L})$ at the same fermentation time. After $120 \mathrm{~h}$, ethanol concentration using $0.15 \%$ and $0.3 \%$ Tween ${ }^{\circledR} 80$ were $1.79 \mathrm{~g} / \mathrm{L}$ and $1.83 \mathrm{~g} / \mathrm{L}$, respectively, representing an increase of approximately $200 \%$ compared to pure ATCC ${ }^{\circledR} 2713$ medium $\left(0.58 \mathrm{~g}\right.$ ethanol/L). The addition of Tween ${ }^{\circledR} 80$ in ATCC ${ }^{2} 2713$ medium resulted in less acetic acid accumulation and higher ethanol production, probably due to the greater availability of inorganic carbon $\left(\mathrm{CO}\right.$ and $\left.\mathrm{CO}_{2}\right)$ and protons (NADH) generated by important Wood-Ljungdahl enzymes as hydrogenases (HYA) and carbon monoxide dehydrogenases (CODH). The surfactant could improve carbon monoxide (CO) and carbon dioxide $\left(\mathrm{CO}_{2}\right)$ availability, resulting not only in more carbon fixation in the pathway but also more proton generation to be consumed in the following steps. 


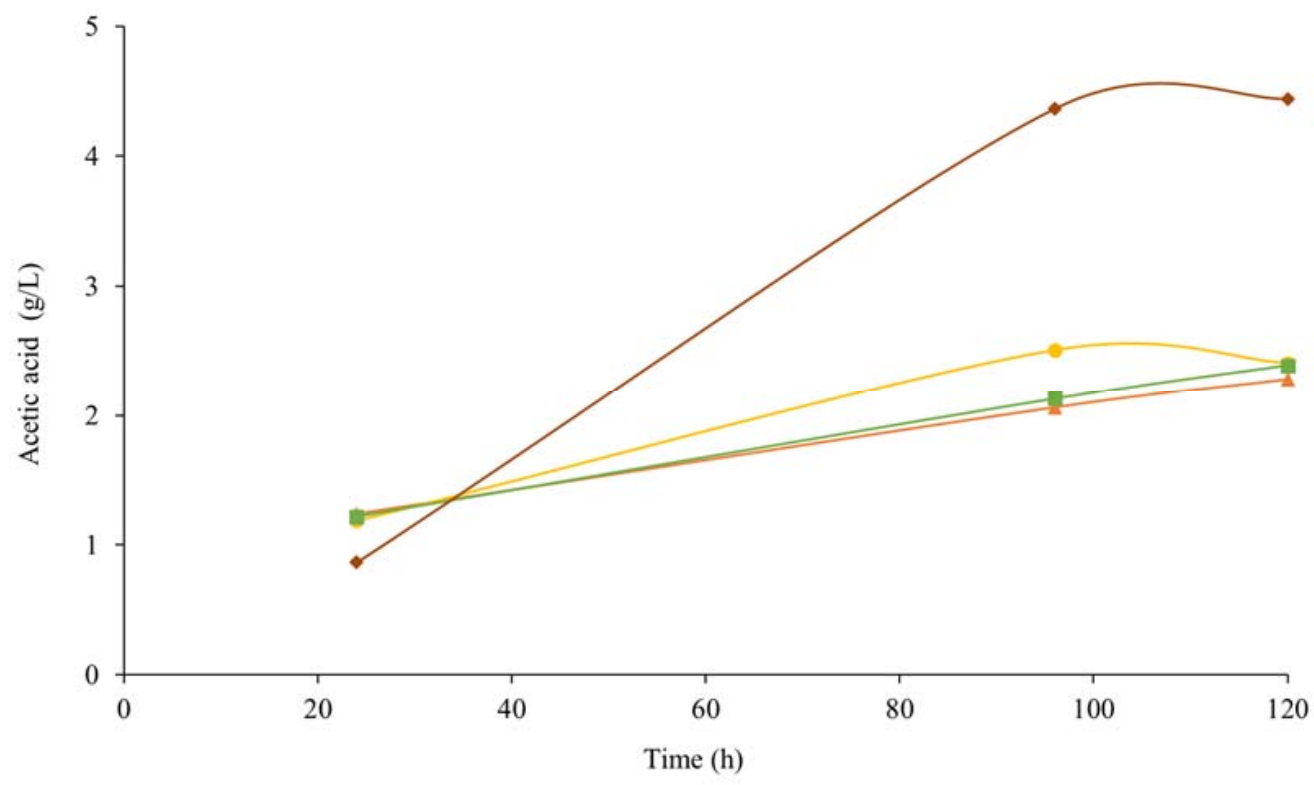

Figure 3. Acetic acid production by Clostridium carboxidivorans during syngas fermentation in ATCC $₫ 2713$ (red diamond), ATCC®2713 with $0.07 \%(v / v)$ Tween $® 80$ (orange triangle), ATCC $₫ 2713$ with $0.15 \%(v / v)$ Tween ${ }^{\circledR} 80$ (yellow circle), and ATCC ${ }^{2} 2713$ with $0.3 \%(v / v)$ Tween ${ }^{\circledR} 80$ (green square).

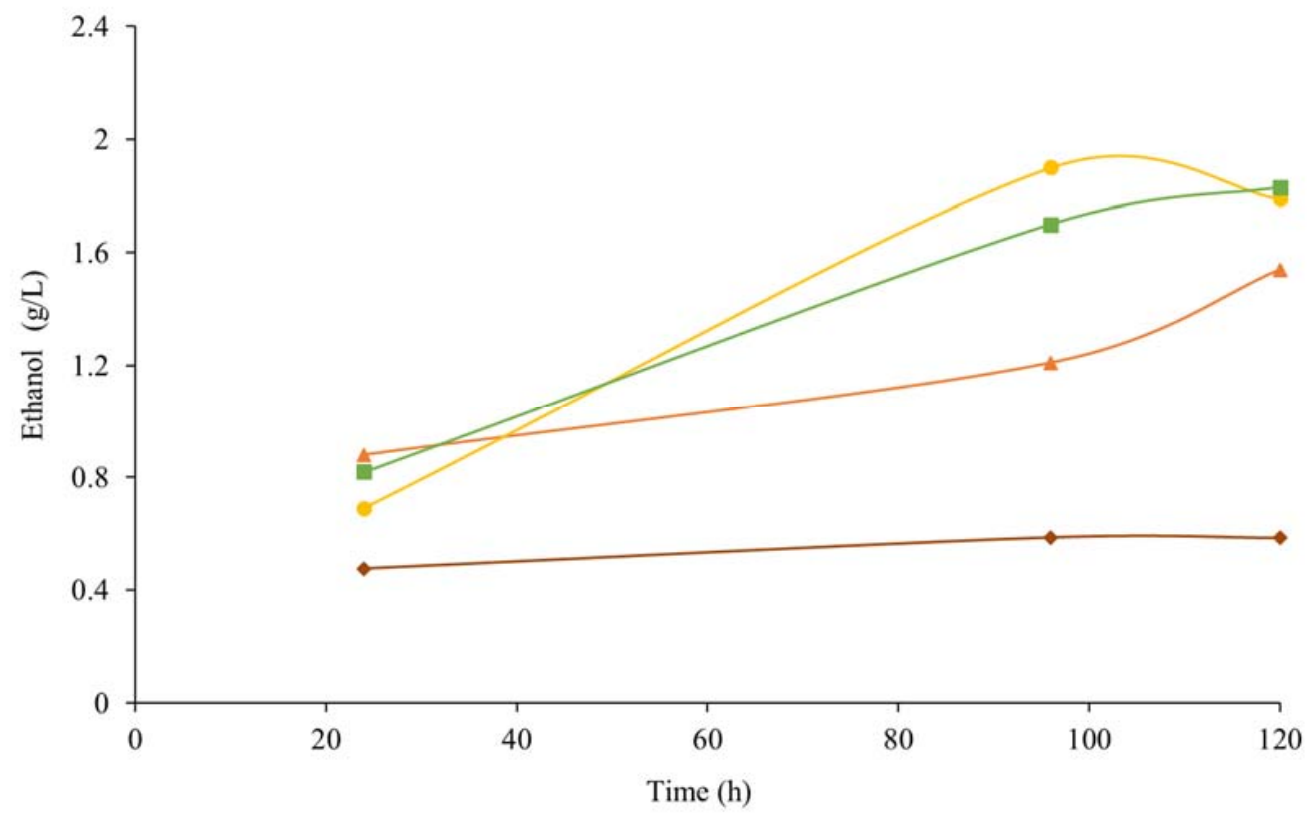

Figure 4. Ethanol production by Clostridium carboxidivorans during syngas fermentation in ATCC $₫ 2713$ (red diamond), ATCC®2713 with $0.07 \%(v / v)$ Tween $₫ 80$ (orange triangle), ATCC 2713 with $0.15 \%(v / v)$ Tween ${ }^{\circledR} 80$ (yellow circle), and ATCC $₫ 2713$ with $0.3 \%(v / v)$ Tween $\AA 80$ (green square).

The highest ethanol productivity was also obtained using $0.15 \%$ Tween $₫ 80(v / v)$, which was $0.02 \mathrm{~g} / \mathrm{L} . \mathrm{h}$ after $96 \mathrm{~h}$ of syngas fermentation. The critical micelle concentration (CMC) of Tween ${ }^{\circledR} 80$ as informed by the supplier (Sigma-Aldrich) is $0.012 \mathrm{mM}$, which is equivalent to $0.15 \%(v / v)$. At CMC, the lowest superficial tension and, therefore, the largest interfacial area between gas and aqueous phase is attained. Probably, better results of ethanol production using $0.15 \%$ Tween $₫ 80$ are related to the increase in mass transfer of the substrates $\left(\mathrm{CO}\right.$ and $\left.\mathrm{CO}_{2}\right)$ from syngas to the aqueous phase for microbial assimilation. There was no butanol production during $120 \mathrm{~h}$ of syngas fermentation by Clostridium carboxidivorans in serum bottles. 
Since the use of ATCC $₫ 2713$ medium with $0.15 \%(v / v)$ Tween $® 80$ Led to higher ethanol production and represented lower cost compared to the medium with $0.30 \%$ Tween $\circledast 80$ $(v / v)$, we decided to use $0.15 \%$ Tween $® 80$ for the validation experiment in stirred tank bioreactor.

\subsection{Stirred Tank Bioreactor Fermentation}

\subsubsection{Cell Growth}

C. carboxidivorans growth in ATCC $® 2713$ medium with $0.15 \%(v / v)$ Tween $₫ 80$ was monitored during $120 \mathrm{~h}$ of syngas fermentation in STBR (Figure 5). As observed in serum bottles, the maximum biomass concentration was also obtained at the beginning of the experiment, followed by a reduction in cell concentration. However, the exponential growth phase was longer in bioreactor fermentation, taking more than $20 \mathrm{~h}$, and the decrease in cell concentration was less deep.

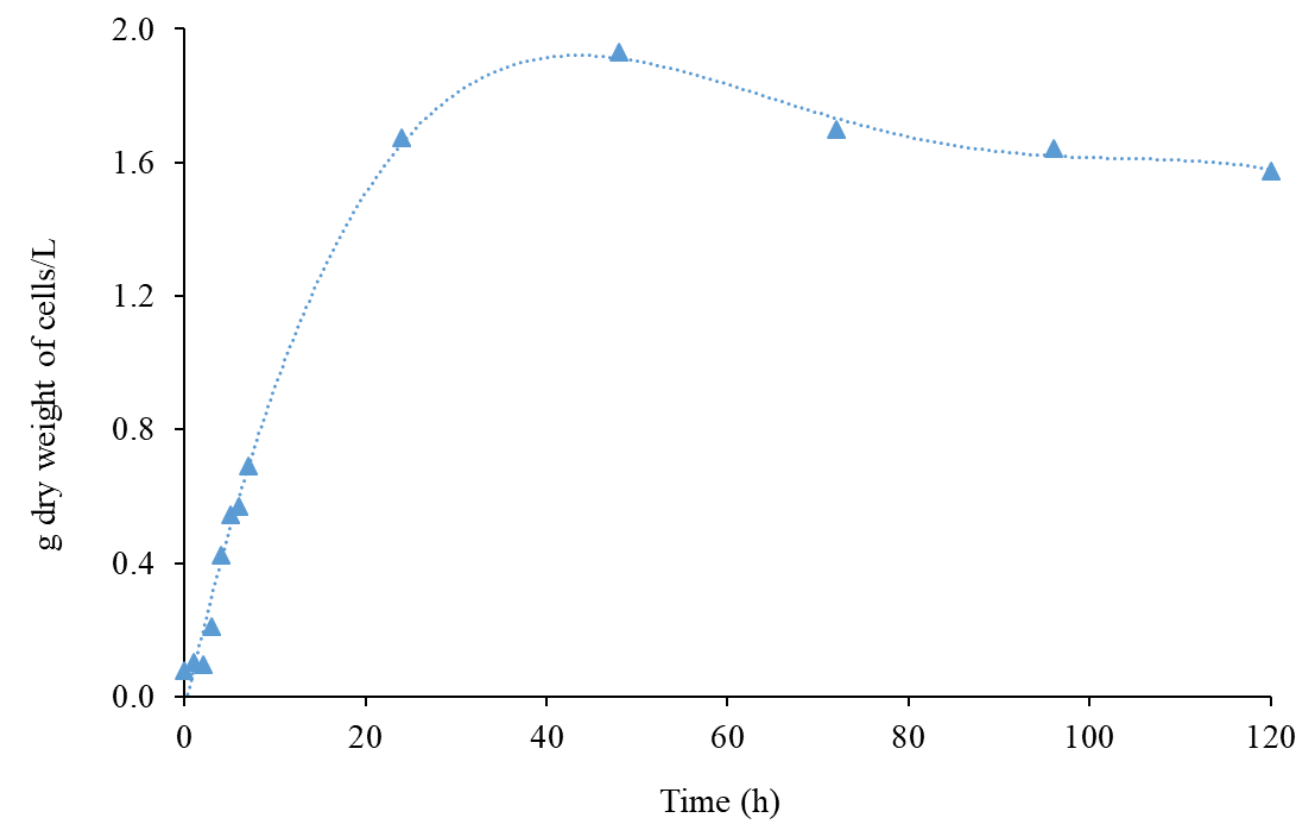

Figure 5. Clostridium carboxidivorans growth during syngas fermentation in ATCC 2713 medium with $0.15 \%(v / v)$ Tween ${ }^{\circledR} 80$ in stirred tank bioreactor.

The lag phase lasted less than $2 \mathrm{~h}$, in accordance to observed in serum bottles fermentation experiments. The maximum biomass concentration and the specific growth rate were $1.93 \mathrm{~g}$ dry weight of cells $/ \mathrm{L}$ and $0.377 \mathrm{~h}^{-1}$, respectively. The biomass production after $120 \mathrm{~h}$ of fermentation in ATCC ${ }^{\circledR} 2713$ with $0.15 \%$ Tween ${ }^{\circledR} 80$ ( $1.67 \mathrm{~g}$ dry weight of cells/L) was $106 \%$ higher than the maximum biomass achieved with the same medium in serum bottle fermentation ( $0.81 \mathrm{~g}$ dry weight of cells/L). This might be related to the greater availability of gaseous substrates in bioreactor configuration since the syngas was fed continuously at a low flow rate, and the better system agitation which probably promoted an increase in mass transfer.

\subsubsection{Metabolites Production}

Unlike most acetogenic bacteria, for which solvents are only detected after the acidogenic phase, during the stationary growth phase [40], ethanol production started along with cell growth for C. carboxidivorans syngas fermentation (Figure 6). According to Shen et al. [41], despite ethanol being considered a non-growth-associated metabolite in C. carboxidivorans syngas fermentation, there is evidence which indicates that it is produced in both growth- and non-growth-associated phases. This can happen because the bacteria can use glucose for growth and the Wood-Ljungdahl pathway to metabolize CO as a carbon 
source for ethanol production simultaneously if the diffusion of the gaseous substrates is efficient [41]. Therefore, it is possible that the contribution of Tween $₫ 80$ to mass transfer induces ethanol production in the exponential growth phase, which continues to increase even after cell growth has stopped.

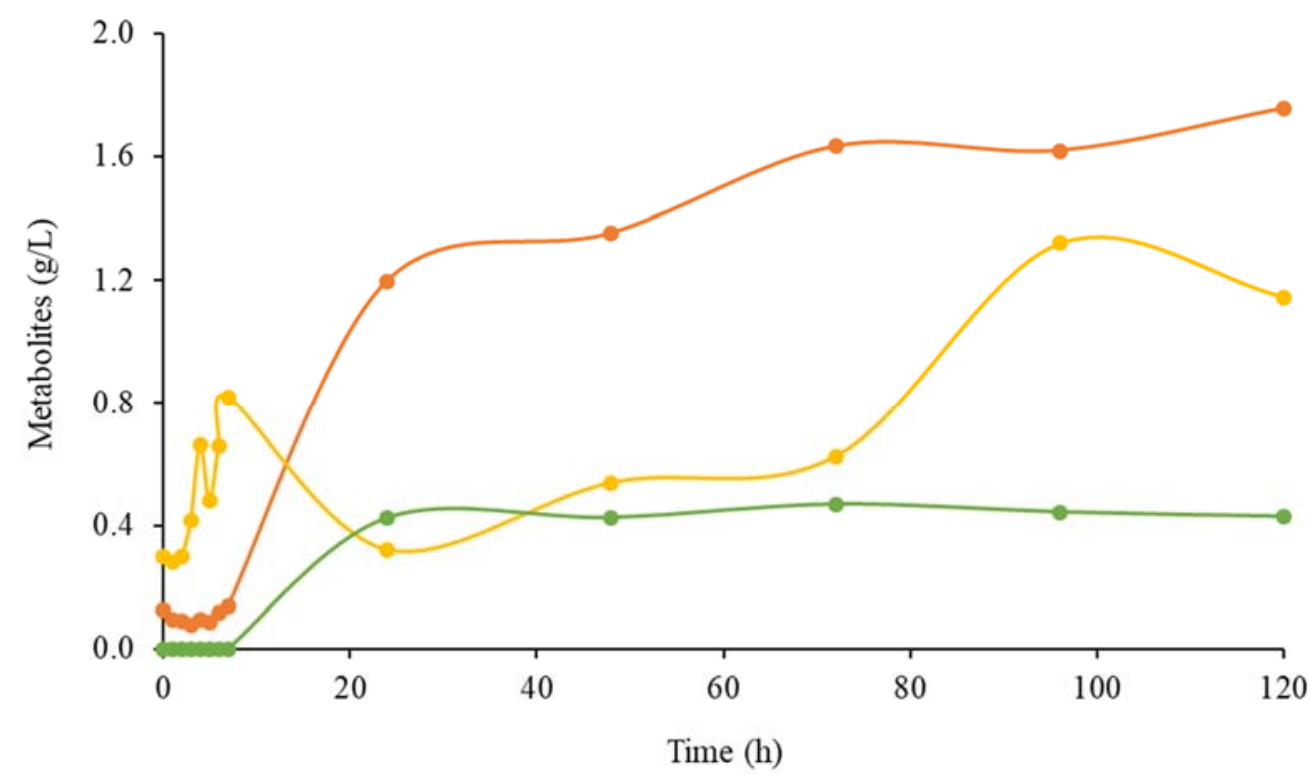

Figure 6. Acetic acid (yellow), ethanol (orange), and butanol (green) production during Clostridium carboxidivorans syngas fermentation in ATCC $(2713$ with $0.15 \%(v / v)$ Tween $₫ 80$ in bioreactor.

The maximum ethanol concentration obtained in STBR after $120 \mathrm{~h}$ in ATCC®2713 medium with $0.15 \%$ Tween $₫ 80$ was $1.76 \mathrm{~g} / \mathrm{L}$. Although biomass production in ATCC®2713 with $0.15 \%$ Tween $\AA 80$ in the bioreactor was much higher $(140 \%)$ than the obtained in serum bottle fermentation, an increase in ethanol production in the bioreactor experiment was not observed. However, productivity was higher because, at $24 \mathrm{~h}$ of fermentation, $1.2 \mathrm{~g} / \mathrm{L}$ of ethanol had already been produced, resulting in $0.050 \mathrm{~g} / \mathrm{L} . \mathrm{h}$, while only $0.69 \mathrm{~g} / \mathrm{L} \mathrm{had}$ been produced in a serum bottle, which resulted in a $44 \%$ lower productivity $(0.028 \mathrm{~g} / \mathrm{L} . \mathrm{h})$.

The maximum acetic acid concentration was obtained after $96 \mathrm{~h}$ in STBR $(1.32 \mathrm{~g} / \mathrm{L})$, $43 \%$ lower than the obtained in serum bottles fermentation $(2.3 \mathrm{~g} / \mathrm{L})$. However, in STBR, butanol production was detected $(0.43 \mathrm{~g} / \mathrm{L}$ after $24 \mathrm{~h})$, which was null in serum bottles experiments

The increase in biomass, ethanol, and butanol productions is probably a result of an enhancement in the gas-liquid mass transfer coefficient due to the bioreactor configuration as well as the addition of Tween ${ }^{\circledR} 80$ in the culture medium as observed in the serum bottles fermentation. Studies have concluded that low concentrations of surface-active additives can affect gas-liquid mass transfer parameters such as the volumetric mass transfer coefficient (kLa) [42,43]. Belo et al. [44] studied the influence of Tween®80 in hydrodynamic parameters and mass transfer of carbon dioxide $\left(\mathrm{CO}_{2}\right)$ in aqueous solution. The presence of Tween ${ }^{\circledR} 80$ generated an important increase in the gas-liquid interfacial area caused by a decrease in the bubble diameter. As reported by Coelho et al. [20], the addition of $0.15 \%(v / v)$ of Tween $® 80$ in water resulted in an increase of $120 \%$ in the carbon monoxide (CO) $\mathrm{kLa}$. This result was obtained using the same bioreactor design and operational conditions as described herein.

Regarding solvent production during cell growth, Shen et al. [12] also reported a similar mixotrophic scenario with $C$. carboxidivorans using a monolithic biofilm reactor in which about $1.5 \mathrm{~g} / \mathrm{L}$ of biomass was produced after $48 \mathrm{~h}$ of fermentation. In the mentioned study, a mineral medium with $10 \mathrm{~g} / \mathrm{L}$ of fructose and a synthetic syngas $\left(20 \% \mathrm{CO}, 5 \% \mathrm{H}_{2}\right.$, $15 \% \mathrm{CO}_{2}, 60 \% \mathrm{~N}_{2}$ ) was used, which explains the fast biomass production when compared to processes that use only inorganic carbon as substrate. In another study using $\mathrm{CO}$ and 
$\mathrm{CO}_{2}$ as carbon sources in a batch fermentation with continuous syngas feed, $0.42 \mathrm{~g} / \mathrm{L}$ of C. carboxidivorans biomass was achieved in $750 \mathrm{~h}$ of processing [45].

\section{Discussion}

The results obtained in the present investigation were compared with similar recent studies reported in the literature (Table 3). Ethanol productivity using $0.15 \%$ Tween $\AA 80$ was $0.050 \mathrm{~g} / \mathrm{L} . \mathrm{h}$, a superior value than was obtained by Doll et al. [14] using two CSTR in series after $200 \mathrm{~h}$ of fermentation, under similar conditions. Fernández-Naveira et al. [36] reported an autotrophic fermentation process with pure carbon monoxide $(\mathrm{CO})$ as substrate in a CSTR with $1.2 \mathrm{~L}$ of working volume. After $245 \mathrm{~h}$ of fermentation, ethanol concentration was $5.6 \mathrm{~g} / \mathrm{L}$, representing lower ethanol productivity than obtained in the present study. Shen et al. [26] reported the highest ethanol productivity using a horizontal rotating packed bed bioreactor $(0.279 \mathrm{~g} / \mathrm{L} . \mathrm{h})$ with pressurized headspace at $29.7 \mathrm{psi}$, which requires high energy consumption and special equipment to support high pressures.

Table 3. Ethanol production from syngas fermentation in different systems.

\begin{tabular}{|c|c|c|c|c|c|c|}
\hline Biocatalysts & Reactor $^{a}$ & $\mathrm{CO}: \mathrm{H}_{2}: \mathrm{CO}_{2}: \mathrm{N}_{2}: \mathrm{CH}_{4}$ & Ethanol (g/L) & $\begin{array}{c}\text { Ethanol } \\
\text { Productivity } \\
\text { (g/L.h) }\end{array}$ & $\begin{array}{l}\text { Fermentation } \\
\text { Period (h) }\end{array}$ & References \\
\hline \multirow{3}{*}{$\begin{array}{l}\text { Clostridium } \\
\text { ragsdalei }\end{array}$} & CSTR & 40:30:30:0:0 & 13.2 & 0.044 & 300 & [11] \\
\hline & TBR & $38: 28: 28: 5: 0$ & 5.7 & 0.003 & 1662 & [46] \\
\hline & TBR & $38: 28: 28: 5: 0$ & 13.2 & 0.158 & 84 & [25] \\
\hline \multirow{8}{*}{$\begin{array}{l}\text { Clostridium } \\
\text { carboxidivorans }\end{array}$} & CSTR & $20: 10: 20: 50: 0$ & 2.7 & 0.008 & 340 & [45] \\
\hline & CSTR & 100:0:0:0:0 & 5.6 & 0.023 & 245 & [36] \\
\hline & CSTR & $20: 10: 20: 50: 0$ & 2.34 & 0.011 & 210 & [45] \\
\hline & CSTR & 30:20:10:40:0 & 5.9 & 0.032 & 185 & [47] \\
\hline & CSTR & $20: 5: 15: 60: 0$ & 2.1 & 0.082 & 25 & [26] \\
\hline & h-RPB & 20:5:15:60:0 & 7 & 0.279 & 25 & [26] \\
\hline & CSTR & 80:0:20:0:0 & 6 & 0.03 & 200 & [14] \\
\hline & STBR & $25: 44: 10: 10: 11$ & 1.2 & 0.050 & 24 & This study \\
\hline \multirow{2}{*}{$\begin{array}{l}\text { Clostridium } \\
\text { ljungdahli }\end{array}$} & CSTR & $65: 30: 5: 0: 0$ & 3.8 & 0.005 & 730 & [48] \\
\hline & HFM & $25: 15: 25: 40: 0$ & 1.09 & 0.005 & 216 & [49] \\
\hline
\end{tabular}

${ }^{a}$ CSTR: continuous stirred tank reactor; TBR: trickle bed reactor; BCR: bubble column reactor; h-RPB: horizontal rotating packed bed biofilm reactor; HFM: hollow fiber membrane; STBR: stirred tank bioreactor.

The highest ethanol productivities from syngas fermentations found in the literature are generally related to sophisticated bioreactor designs (TBR [25], h-RPB [26]), which are difficult to scale up and operate, especially because of the preliminary step of film formation needed for these bioreactors. Considering that in this study, we proposed a continuous syngas feed at a very low flow rate and a simple reactor configuration, with no pressure or $\mathrm{pH}$ control. The ethanol productivity obtained was promising compared to studies reported in the literature using similar substrates, operational conditions, and microorganisms. Tween ${ }^{\circledR 80}$ is a relatively cheap input (US \$30/L at MilliporeSigma website-https:/ / www.sigmaaldrich.com/US/en, accessed on 30 July 2021), and a small amount is needed to increase ethanol production $(0.0015 \mathrm{~L}$ per liter of culture medium). Moreover, it is suitable for microbial culture, without toxicity to bacterial cells [29]. Although Bredweel et al. [29] have tested Tween $₫ 80$ in carbon monoxide fermentation, this is the first report in the literature concerning the effect of different concentrations of Tween ${ }^{\circledR 8} 8$ in syngas fermentations and its validation in bioreactor scale. Tween ${ }^{\circledR} 80$ can cause foam depending on concentration, medium composition, mechanical agitation, and gas flow rate, and serum bottles do not evaluate this problem. We have validated the use of Tween $₫ 80$ in syngas fermentation in a bioreactor since we detected product formation and no foam was observed. Besides, the gas composition used herein is much more realistic when compared to syngas obtained from waste material pyrolysis [50]. Further research is needed to 
evaluate syngas composition after fermentation to verify the variability of $\mathrm{CO}, \mathrm{CO}_{2}$, and $\mathrm{H}_{2}$ consumption with and without Tween $₫ 80$ to provide in-depth understanding of its effect.

\section{Conclusions}

The effect caused by the addition of Tween $₫ 80$ to ATCC $₫ 2713$ medium was evidenced by an increase in biomass and ethanol production during Clostridium carboxidivorans syngas fermentation in serum bottles and validated in a stirred tank bioreactor. The presence of this surfactant probably led to the reduction of bubble size, increasing the gas-liquid interfacial area, which resulted in the increase of $\mathrm{CO}$ and $\mathrm{CO}_{2}$ mass transfer coefficients. The biomass and ethanol productions increased by $15 \%$ and $200 \%$ using Tween $₫ 80$ in the culture medium, respectively, compared to pure ATCC®2713 medium. In a bioreactor, $106 \%$ more biomass was produced compared to serum bottle fermentation, but the same ethanol concentration was achieved.

Author Contributions: C.B., T.F., and P.A. conceived and planned the experiments. C.B., A.B., M.B., and M.d.N.-C. carried out the experiments. C.B. and M.B. were responsible for analyses. C.B. wrote the manuscript with support from T.F. and P.A. T.F. and P.A. supervised the project. All authors provided critical feedback and helped shape the research, analysis, and manuscript. All authors have read and agreed to the published version of the manuscript.

Funding: This research was funded by Fundação Carlos Chagas Filho de Amparo à Pesquisa do Estado do Rio de Janeiro, grant number FAPERJ-E-26/010.002984/2014, and Conselho Nacional de Desenvolvimento Científico e Tecnológico, grant number CNPq-PQ/2 308626/2019-2.

Institutional Review Board Statement: Not applicable.

Informed Consent Statement: Not applicable.

Acknowledgments: The group would like to acknowledge Nei Pereira Jr. and Roberta Ribeiro for intellectual guidance. We thank SENAI's Innovation Institute for Biosynthetic for the use of Cell Growth Quantifier (CGQ) sensors from Aquila Biolabs for cell growth measurement in real-time through non-invasive technology.

Conflicts of Interest: The authors declare no conflict of interest.

\section{References}

1. EIA with Projections to 2050. Available online: https://www.eia.gov/outlooks/aeo/ (accessed on 12 August 2021).

2. Gildemyn, S.; Molitor, B.; Usack, J.G.; Nguyen, M.; Rabaey, K.; Angenent, L.T. Upgrading syngas fermentation effluent using Clostridium kluyveri in a continuous fermentation. Biotechnol. Biofuels 2017, 10, 1-15. [CrossRef] [PubMed]

3. Mohammadi, M.; Najafpour, G.D.; Younesi, H.; Lahijani, P.; Uzir, M.H.; Mohamed, A.R. Bioconversion of synthesis gas to second generation biofuels: A review. Renew. Sustain. Energy Rev. 2011, 15, 4255-4273. [CrossRef]

4. Ukpong, M.N.; Atiyeh, H.K.; De Lorme, M.J.M.; Liu, K.; Zhu, X.; Tanner, R.S.; Wilkins, M.R.; Stevenson, B.S. Physiological response of Clostridium carboxidivorans during conversion of synthesis gas to solvents in a gas-fed bioreactor. Biotechnol. Bioeng. 2012, 109, 2720-2728. [CrossRef]

5. Benevenuti, C.; Botelho, A.; Ribeiro, R.; Branco, M.; Pereira, A.; Vieira, A.C.; Ferreira, T.; Amaral, P. Experimental Design to Improve Cell Growth and Ethanol Production in Syngas Fermentation by Clostridium carboxidivorans. Catalysts 2020, 10, 59. [CrossRef]

6. Munasinghe, P.C.; Khanal, S.K. Biomass-derived syngas fermentation into biofuels. Biofuels 2011, 101, 79-98.

7. Sun, Y.; Cheng, J. Hydrolysis of lignocellulosic materials for ethanol production: A review. Bioresour. Technol. 2002, 83, 1-11. [CrossRef]

8. Boboescu, I.Z.; Gélinas, M.; Beigbeder, J.B.; Lavoie, J.M. A two-step optimization strategy for 2nd generation ethanol production using softwood hemicellulosic hydrolysate as fermentation substrate. Bioresour. Technol. 2017, 244, 708-716. [CrossRef] [PubMed]

9. Datar, R.P.; Shenkman, R.M.; Cateni, B.G.; Huhnke, R.L.; Lewis, R.S. Fermentation of biomass-generated producer gas to ethanol. Biotechnol. Bioeng. 2004, 86, 587-594. [CrossRef]

10. Lewis, R.S.; Tanner, R.S.; Huhnke, R.L. Huhnke Indirect or Direct Fermentation of Biomass to Fuel Alcohol. U.S. Patent No. 11/441,392, 25 May 2006.

11. Sun, X.; Atiyeh, H.K.; Zhang, H.; Tanner, R.S.; Huhnke, R.L. Enhanced ethanol production from syngas by Clostridium ragsdalei in continuous stirred tank reactor using medium with poultry litter biochar. Appl. Energy 2019, 236, 1269-1279. [CrossRef]

12. Shen, Y.; Brown, R.; Wen, Z. Syngas fermentation of Clostridium carboxidivoran P7 in a hollow fiber membrane biofilm reactor: Evaluating the mass transfer coefficient and ethanol production performance. Biochem. Eng. J. 2014, 85, 21-29. [CrossRef] 
13. Liberato, V.; Benevenuti, C.; Coelho, F.; Botelho, A.; Amaral, P.; Pereira, N.; Ferreira, T. Chemicals production in a biorefinery context. Catalysts 2019, 9, 962. [CrossRef]

14. Doll, K.; Rückel, A.; Kämpf, P.; Wende, M.; Weuster-Botz, D. Two stirred-tank bioreactors in series enable continuous production of alcohols from carbon monoxide with Clostridium carboxidivorans. Bioprocess. Biosyst. Eng. 2018, 41, 1403-1416. [CrossRef]

15. Dürre, P.; Eikmanns, B.J. C1-carbon sources for chemical and fuel production by microbial gas fermentation. Curr. Opin. Biotechnol. 2015, 35, 63-72. [CrossRef]

16. Kennes, D.; Abubackar, H.N.; Diaz, M.; Veiga, M.C.; Kennes, C. Bioethanol production from biomass: Carbohydrate vs. syngas fermentation. J. Chem. Technol. Biotechnol. 2016, 91, 304-317. [CrossRef]

17. Zhang, J.; Taylor, S.; Wang, Y. Effects of end products on fermentation profiles in Clostridium carboxidivorans P7 for syngas fermentation. Bioresour. Technol. 2016, 218, 1055-1063. [CrossRef] [PubMed]

18. Kundiyana, D.K.; Huhnke, R.L.; Wilkins, M.R. Syngas fermentation in a 100-L pilot scale fermentor: Design and process considerations. J. Biosci. Bioeng. 2010, 109, 492-498. [CrossRef]

19. Richter, H.; Martin, M.E.; Angenent, L.T. A two-stage continuous fermentation system for conversion of syngas into ethanol. Energies 2013, 6, 3987-4000. [CrossRef]

20. Coelho, F.M.B.; Botelho, A.M.; Ivo, O.F.; Amaral, P.F.F.; Ferreira, T.F. Volumetric mass transfer coefficient for carbon monoxide in a dual impeller stirred tank reactor considering a perfluorocarbon-water mixture as liquid phase. Chem. Eng. Res. Des. 2019, 160-169. [CrossRef]

21. Phillips, J.R.; Huhnke, R.L.; Atiyeh, H.K. Syngas fermentation: A microbial conversion process of gaseous substrates to various products. Fermentation 2017, 3, 28. [CrossRef]

22. Fernández-Naveira, Á.; Veiga, M.C.; Kennes, C. Effect of salinity on C1-gas fermentation by Clostridium carboxidivorans producing acids and alcohols. AMB Express 2019, 9, 1-11. [CrossRef] [PubMed]

23. Shen, Y.; Brown, R.; Wen, Z. Enhancing mass transfer and ethanol production in syngas fermentation of Clostridium carboxidivorans P7 through a monolithic biofilm reactor. Appl. Energy 2014, 136, 68-76. [CrossRef]

24. Coelho, F.M.B.; Nele, M.; Ribeiro, R.R.; Ferreira, T.F.; Amaral, P.F.F. Clostridium carboxidivorans' surface characterization using contact angle measurement (CAM). In Proceedings of the IConBM2016 2nd International Conference on BIOMASS, Sicily, Italy, 19-22 June 2016; Volume 50, pp. 277-282.

25. Devarapalli, M.; Lewis, R.S.; Atiyeh, H.K. Continuous ethanol production from synthesis gas by Clostridium ragsdalei in a trickle-bed reactor. Fermentation 2017, 3, 23. [CrossRef]

26. Shen, Y.; Brown, R.C.; Wen, Z. Syngas fermentation by Clostridium carboxidivorans P7 in a horizontal rotating packed bed biofilm reactor with enhanced ethanol production. Appl. Energy 2017, 187, 585-594. [CrossRef]

27. Aldric, J.M.; Gillet, S.; Delvigne, F.; Blecker, C.; Lebeau, F.; Wathelet, J.P.; Manigat, G.; Thonart, P. Effect of surfactants and biomass on the gas / liquid mass transfer in an aqueous-silicone oil two-phase partitioning bioreactor using Rhodococcus erythropolis T902. 1 to remove VOCs from gaseous effluents. J. Chem. Technol. Biotechnol. 2009, 84, 1274-1283. [CrossRef]

28. Rehman, F.; Medley, G.J.D.; Bandulasena, H.; Zimmerman, W.B.J. Fluidic oscillator-mediated microbubble generation to provide cost effective mass transfer and mixing ef fi ciency to the wastewater treat- ment plants. Environ. Res. 2015, 137, 32-39. [CrossRef] [PubMed]

29. Bredwell, M.D.; Telgenhoff, I.M.D.; Barnard, I.S.; Worden, R.M.I. Effect of surfactants on carbon monoxide fermentations by butyribacterium methylotroph icum. Appl. Biochem. Biotechnol. 1997, 63-65, 637-647. [CrossRef]

30. Myung, J.; Kim, M.; Pan, M.; Criddle, C.S.; Tang, S.K.Y. Bioresource technology low energy emulsion-based fermentation enabling accelerated methane mass transfer and growth of poly (3-hydroxybutyrate) -accumulating methanotrophs. Bioresour. Technol. 2016, 207, 302-307. [CrossRef] [PubMed]

31. Nielsen, C.K.; Kjems, J.; Mygind, T.; Snabe, T.; Meyer, R.L. Effects of tween 80 on growth and biofilm formation in laboratory media. Front. Microbiol. 2016, 7, 1-10. [CrossRef] [PubMed]

32. Eskandani, M.; Hamishehkar, H.; Dolatabadi, J.E.N. Cyto/genotoxicity study of polyoxyethylene (20) sorbitan monolaurate (tween 20). DNA Cell Biol. 2013, 32, 498-503. [CrossRef] [PubMed]

33. Yasin, M.; Park, S.; Jeong, Y.; Lee, E.Y.; Lee, J.; Chang, I.S. Effect of internal pressure and gas/liquid interface area on the CO mass transfer coefficient using hollow fibre membranes as a high mass transfer gas diffusing system for microbial syngas fermentation. Bioresour. Technol. 2014, 169, 637-643. [CrossRef]

34. Rodrigues, V.; Alberto, C.; Cosenza, N.; Barros, C.F.; Krykhtine, F.; Netto, E.; Fortes, S.; Alberto, C.; Cosenza, N.; Barros, C.F. Tratamento de resíduos sólidos urbanos e produção de energia: Análise de legislação para viabilidade econômica de soluçoes. In Proceedings of the XI Simpósio de Excelência em Gestão e Tecnologia-SEGeT, Rio de Janeiro, Brazil, 22-24 October 2014.

35. Ribeiro, R.R.; Coelho, F.; Ferreira, T.F.; Amaral, P.F.F. A new strategy for acetogenic bacteriacell growth and metabolites production using syngas in lab scale. IOSR J. Biotechnol. Biochem. 2017, 03, 27-30. [CrossRef]

36. Fernández-Naveira, Á.; Abubackar, H.N.; Veiga, M.C.; Kennes, C. Carbon monoxide bioconversion to butanol-ethanol by Clostridium carboxidivorans: Kinetics and toxicity of alcohols. Appl. Microbiol. Biotechnol. 2016, 100, 4231-4240. [CrossRef] [PubMed]

37. Fernández-Naveira, Á.; Abubackar, H.N.; Veiga, M.C.; Kennes, C. Efficient butanol-ethanol (B-E) production from carbon monoxide fermentation by Clostridium carboxidivorans. Appl. Microbiol. Biotechnol. 2016, 100, 3361-3370. [CrossRef] 
38. Ogata, S. Morphological changes during conversion of clostridium saccharoperbutylacetonicum to protoplasts by sucrose-induced autolysis. Microbiol. Immunol. 1980, 24, 393-400. [CrossRef]

39. Daniell, J.; Köpke, M.; Simpson, S.D. Commercial biomass syngas fermentation. Energies 2012, 5, 5372-5417. [CrossRef]

40. Fernández-Naveira, Á.; Veiga, M.C.; Kennes, C. Glucose bioconversion profile in the syngas-metabolizing species Clostridium carboxidivorans. Bioresour. Technol. 2017, 244, 552-559. [CrossRef]

41. Shen, S.; Gu, Y.; Chai, C.; Jiang, W.; Zhuang, Y.; Wang, Y. Enhanced alcohol titre and ratio in carbon monoxide-rich off-gas fermentation of Clostridium carboxidivorans through combination of trace metals optimization with variable-temperature cultivation. Bioresour. Technol. 2017, 239, 236-243. [CrossRef]

42. Vasconcelos, J.M.T.; Rodrigues, J.M.L.; Orvalho, S.C.P.; Alves, S.S.; Mendes, R.L.; Reis, A. Effect of contaminants on mass transfer coefficients in bubble column and airlift contactors. Chem. Eng. Sci. 2003, 58, 1431-1440. [CrossRef]

43. Blanco, A.; García-Abuín, A.; Gómez-Díaz, D.; Navaza, J.M. Hydrodynamic and absorption studies of carbon dioxide absorption in aqueous amide solutions using a bubble column contactor. Brazilian J. Chem. Eng. 2013, 30, 801-809. [CrossRef]

44. Belo, I.; García-Abuín, A.; Gómez-Díaz, D.; Navaza, J.M.J.M.; Vidal-Tato, I. Effect of tween 80 on bubble size and mass transfer in a bubble contactor. Chem. Eng. Technol. 2011, 34, 1790-1796. [CrossRef]

45. Fernández-Naveira, Á.; Veiga, M.C.; Kennes, C. Effect of pH control on the anaerobic H-B-E fermentation of syngas in bioreactors. J. Chem. Technol. Biotechnol. 2017, 92, 1178-1185. [CrossRef]

46. Devarapalli, M.; Atiyeh, H.K.; Phillips, J.R.; Lewis, R.S.; Huhnke, R.L. Ethanol production during semi-continuous syngas fermentation in a trickle bed reactor using Clostridium ragsdalei. Bioresour. Technol. 2016, 209, 56-65. [CrossRef] [PubMed]

47. Fernández-naveira, Á.; Veiga, M.C.; Kennes, C. Selective anaerobic fermentation of syngas into either $\mathrm{C}_{2}-\mathrm{C}_{6}$ organic acids or ethanol and higher alcohols. Bioresour. Technol. 2019, 280, 387-395. [CrossRef] [PubMed]

48. Acharya, B.; Dutta, A.; Basu, P. Ethanol production by syngas fermentation in a continuous stirred tank bioreactor using Clostridium ljungdahlii. Biofuels 2019, 10, 221-237. [CrossRef]

49. Anggraini, I.D.; Kery, K.; Bandung, P.N.; Kresnowati, P.; Purwadi, R. Bioethanol production via syngas fermentation of clostridium ljungdahlii in a hollow fiber membrane supported bioreactor. Chem. Eng. 2019, 10, 481-490. [CrossRef]

50. Das, P.; Chandramohan, V.P.; Mathimani, T.; Pugazhendhi, A. Recent advances in thermochemical methods for the conversion of algal biomass to energy. Sci. Total Environ. 2021, 766, 144608. [CrossRef] 